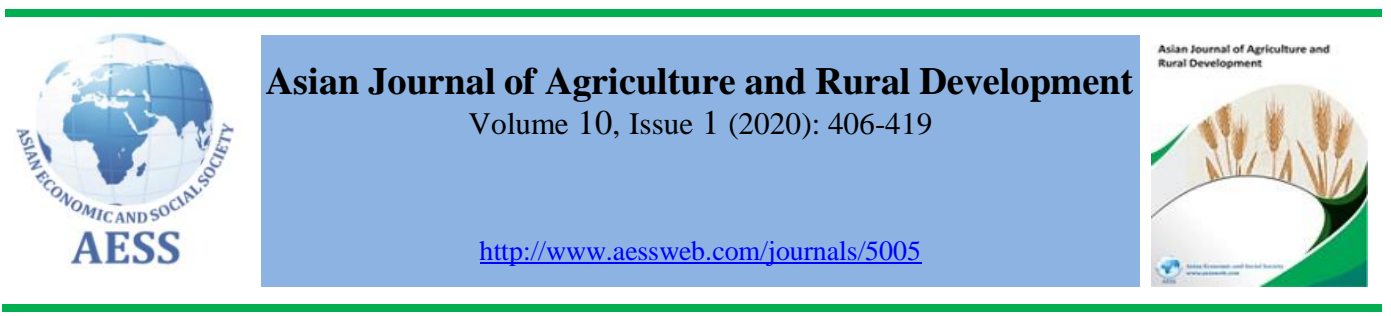

\title{
FARMERS' ATTITUDE AND BEHAVIOR TOWARD SAVINGS IN IKA SOUTH LOCAL GOVERNMENT AREA OF DELTA STATE, NIGERIA
}

\author{
(1) Rodney Akpoviri a Delta State University, Asaba Campus, Nigeria \\ Isiorhovoja $^{\text {a }}$, \\ Solomon \\ - raisiorhovoja@gmail.com (Corresponding author) \\ Okeoghene Ebewore a,
}

Salome Nwachi ${ }^{\text {a }}$

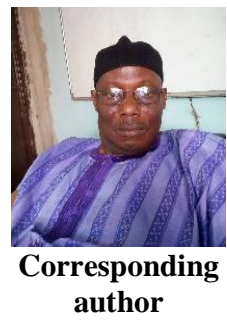

\section{ARTICLE HISTORY:}

Received: 24-Jan-2020

Accepted: 04-May-2020

Online Available: 17-Jun-

2020

\section{Keywords:}

Commercial banks,

Experience,

Farmers' needs,

Income

\begin{abstract}
The study ascertained the attitude of farmers towards saving behaviour in Ika South Local Government Area of Delta State, Nigeria. The data were collected by questionnaires and analyzed using descriptive statistics and logistic regression. The results revealed that the mean age of respondents was 47 years, majority of farmers' were male $(62 \%)$ and had formal education $(66.2 \%)$, mean household size was four persons and farm size had a mean of 2.9 hectares. Farmers have a positive attitude towards saving but were not comfortable with commercial banks. They, however, seek alternative avenues for savings. Level of education, farm size, and years of farming experience were significant determinants of savings. Three top challenges to savings were inadequate income, family responsibility, and cost of inputs. It was recommended that policies that increase farm size/boost farm income be pursued and that commercial banks should pay particular attention to the needs of farmers in service administration to encourage them to develop a positive attitude towards commercial banks.
\end{abstract}

\section{Contribution/ Originality}

The paper identified the causes of low savings among rural farmers in Delta State, Nigeria. It also categorized the poor saving habits of farmers with commercial banks. Solutions were thus provided along with the causes/nature of the challenges to saving identified.

DOI: 10.18488/journal.1005/2020.10.1/1005.1.406.419

ISSN (P): 2304-1455/ISSN (E):2224-4433

How to cite: Rodney Akpoviri Isiorhovoja, Solomon Okeoghene Ebewore and Salome Nwachi (2020). Farmers' attitude and behavior toward savings in Ika south local government area of delta state, Nigeria. Asian Journal of Agriculture and Rural Development, 10(1), 406-419. 


\section{INTRODUCTION}

Equity and debt are the two types of investment funds available to any business (Sitharam and Hoque, 2016). They are obtainable from two broad sources namely; informal or non-institutional sources and the formal or institutional sources (Fadeyi, 2018). Funds from the informal sources may be from personal/farm business saving, friends, and relatives. Loans from friends and relatives are usually interest-free but very limited in supply terms of the needs of the farmers. Local farmers also obtain loans from a rotating saving scheme. It is locally called "Esusu" or "Isusu" or "Osusu" in Nigeria, depending on the dialect of the individual. It is a type of self-help for accessing a relatively high volume of loans either by rotation or at request (Fadeyi, 2018). Beyond the esusu is the farmers' cooperative society the operation of which is guided by rules, regulations, and by-laws provided by the designated State/federal government ministry. Hence in strict classification, it is described as semi-formal (Silong and Gadanakis, 2019) or quasi source.

Still part of informal sources of loan is the private money lenders. This source of loan is characterized by the prohibitive interest rates charged on the borrowed fund. They therefore only serve as last resort to smallholder farmers. Fadeyi (2018) recommend that it is better to avoid them.

Formal sources of funds are outright loans (debt) funds. They come from widely varied sources in terms of agency and instruments for loan delivery. Here, the use of Commercial banks as a source of loan funds to the smallholder to medium enterprise farmers is assuming greater importance notwithstanding the stiff conditions for obtaining such loans and the high-interest rate charged (Fadeyi, 2018) coupled with the high competition from investors, especially from the industrial sector. These factors acting together effectively curtail loan access by farmers such as to make for poor access (Rahji and Adeoti, 2010). Commercial banks' unwillingness to advance adequate volume and the number of loans to the smallholder farmers may be further accounted for by the non-realization of expected impacts of such loans (Fadeyi, 2018). this conclusion was reached by the author after reviewing 59 relevant articles. However, the existence of a positive correlation between loan and farm output is not removed (Oyelade et al., 2019).

The scale of development activity could affect the relevance of any loan source to an intending borrower since the capacity of a particular loan source to meet the loan requirement of a development project may be grossly inadequate. Waniak et al. (2018) for example, do not recognize personal savings and funds from friends and family as a source of financing development activity but give high recognition to bank loans, leasing, franchise, and capital market. These sources of credit funds which attracts relatively low-interest rate we have noted are not easily accessible to the resource-poor farmers, hence sources such as capital market, leasing and franchise may not also be recognized or counted as sources of loan for the resource-poor farmer.

Farmers are resource-poor and farm productivity and output are low whereas the average size of the farm family is large (Anderson et al., 2017). Farm income alone is therefore inadequate to satisfy the family consumption needs. That these farmers save at all, therefore, requires a deliberate determination to defer current consumption. Thus savings made whether in cash or kind can hardly be adequate for the farm business needs. This is to say that farmers' savings as a source of investment fund for agriculture (Odoemenem et al., 2013) are hidebound. However, saving enhances the framers' credit rating for loan access and serves as a risk management strategy (Zeller and Sharma, 2000). That saving enhances farmers' access to credit further amplify the compulsion to save if the farmers must access bank loans.

Apart from farm income, various other factors influence farmers' saving ability. These factors replete economics literature, however, some of them are the willingness to save, educational level, and occupation, among others. These variables change over time and responses to them also vary depending on the socioeconomic environments (Anang et al., 2015) and the personal characteristics 
of the individual farmer which also, is subject to change. Research results from one area may therefore not reflect adequately conditions in another area neither can it be valid for all time, hence the need for continuous studies which will facilitate keeping tab of the changing socioeconomic environment to influence it in favour of effective management of the attitude and behaviour of farmers towards saving.

Agriculture as a major employer of labour in Nigeria engages about $70 \%$ of the population. By this, agriculture serves as a source of income to a large proportion of the population. However, the sector provides a low capacity for savings, worse still a capacity that is on a downturn. Thus agriculture offers little or no opportunity for escaping out of the cycle of poverty (Albu and Scott, 2001; Anderson et al., 2017) without elaborate intervention.

Given that the factors that influence saving vary over time and that they too can be influenced, successive governments in Nigeria have over time, tried many policies and programmes to boost farmers' saving behaviour some of which are the Rural Banking scheme which became operational in 1977, the Bank of Agriculture (BOA) which existed under different names and scope from 1973 until 2000 when it was so christened after the merging of two other poverty alleviation programmes and, the Agricultural Credit Guarantee Scheme Fund (ACGSF) of 1978 among others, to facilitate access to credit, expand farm business, boost farm output and income and generate surplus for saving and to bolster equity fund to the farm business. It is therefore rational to expect that the factors which influence farmers' ability to save may have changed; hence the question as to what is the attitude of farmers to saving given the relatively increased spread of banking facilities across Delta State, Nigeria and what is their saving behavior given government support programmes.

There are several published research papers on farmers' saving habits across the globe. Some of these authors like: Obayelu (2012) did his work on Kwara State, Nigeria; Osondu et al. (2015) worked on Abia State; Anang et al. (2015) studied the Tolon-kumbungu district of Ghana; and Ghafoor et al. (2010) who studied the situation in the Punjab district of Pakistan, among others. Obayelu (2012) identified economic reasons why saving behavior in developing economies may deviate from what obtains in the developed worlds. Beyond these, empirical research lends credence to both the attitudinal and behavioral nature saving. This informs the topic under review.

The word attitude comes from the Latin word aptus which means to be in good shape and prepared for action. Attitude is not directly observable but it is largely believed to precede behavior and to also guide choices and decisions (Hogg and Vaughan, 2005). There are three components to it; namely, (i) thought and ideas, (ii) feelings of likes and dislikes and, (iii) behavior. Hogg and Vaughan (2005) opine that behavior is hinged on a lasting system of beliefs and feelings and, subsequently, directed towards objects which are considered significant socially. Such an object in this circumstance will include savings itself and the various programmes and institutions put in place to generate savings and mobilize them.

The broad objective of this study is to determine farmers' attitudes and behavior toward saving. The specific objectives are to:

i. Determine the attitude of farmers towards saving

ii. Determine the behavior of farmers towards saving

iii. Identify the factors that affect saving, and

iv. Identify challenges to saving by farmers.

The hypotheses tested were:

i. Ho1: Farmers attitude towards saving is not positive

ii. $\mathrm{Ho}_{2}$ : Socioeconomic factors have no significant effect on farmers' saving behavior 


\section{MATERIALS AND METHODS}

The study area is Ika South Local Government Area (LGA), situated to the North West of Delta State Nigeria, with its headquarters at Agbor, the only commercial town. Delta State is bounded by longitude $5^{0}$ and $6^{0} 45^{1}$ East and latitude $5^{0} 20^{1}$ and $6^{0} 30^{1}$ North of the Equator. The choice of Delta State was informed by its proximity to the authors, more importantly by the fact that the State is oil-producing. Crude oil exploration and exploitation have seriously degraded farmlands and many individuals have quit farming in preference for non-existing jobs in the petroleum sector, interestingly citizens of the LGA considered in this study remain in their farmland.

The choice of this LGA is founded on a combination of economic and commercial factors. For economic reasons, Ika South LGA is about the food basket of the state. Farming is the major occupation of this LGA. All the women, men, and children are involved. The use of motorcycles and bicycles for farming activities are very popular here, a phenomenon that can hardly be found elsewhere in the state. Major staple food crops of cassava and all its derivatives, yam, banana, and plantain are produced here. Fruits and vegetables such as pineapple, oranges, and pumpkin leaf are also produced in the LGA. Apart from Agbor, the LGA headquarters, and the only commercial city, the rural markets in the LGA attract traders from most of the state; traders who come to buy food items for sale, some in the major markets across the state and others in community retails shops. Thus commerce as secondary occupation is essentially agriculture-based carried out by middlemen who buy at the farm gate for resale on market days for a margin.

Unfortunately, however, there is a palpable deficit in the spread of banks in rural farming communities. The commercial banks are concentrated at the LGA headquarters, thus likely to have an adverse effect on the banking habits and the attitude to saving and saving practices of these farmers. This curious scenario raises several questions as to: (i) what is the farmers' view of banking? and (ii) what is their attitude to saving and saving practices?

The field survey was conduct November in 2018. Respondents were drawn using a multistage sampling procedure. The first stage was the purposive sampling of five wards from the 19 wards in the LGA where agriculture is the major economic activity. The second stage was the random selection of 35 farmers from each selected ward, hence a sample size of 175 . However, 150 of the returned copies of the questionnaire were admissible for this study. There were three sections in the questionnaire. Section A collected information on the personal identity and socioeconomic characteristics of the farmers, Section B collected information on attitude to saving and, Section C elicited information on saving behavior. Questions on attitude to saving and saving behavior were adapted from Furnham (1999). They were presented on a four-point Likert type scale with scores as strongly disagree (1), disagree (2), agree (3), and strongly agree (4) or as a binary variable of yes (1) and no (0). Items in the questionnaire would be found in Tables 2 to 4 . Data were analyzed with the aid of IBM SPSS statistic 20 using descriptive statistics (frequency count, mean, and standard deviation to summarize the data) and logistic regression. Hypothesis one, that is, farmers' attitude towards saving is not above average was tested using a one-sample t-test with 2.50 as the test value. Hypothesis two, that is, Socioeconomic factors have no significant effect on farmers' saving behavior was tested using logistic regression. The logistic regression model is stated as:

$$
f(Z)=\frac{1}{1+e^{-z}}
$$

Where:

$f(Z)$ is the binary dependent variable of the farmers who save (1) or do not save (0). The exponent of the predictor variables $\left(\mathrm{e}^{\mathrm{z}} \mathrm{z}\right)$ represents the log-odds in favour of the respondent that does not save and $\mathrm{z}$ is a vector of predictor variables specified as: 


$$
Z=b_{0}+b_{1} x_{1}+b_{2} x_{2}+. . b_{n} x_{n}
$$

Socio economic characteristics of farmers

$\mathrm{X}_{1}=$ Age of farmer (Age)

$\mathrm{X}_{2}=$ Educational level (Edu)

$\mathrm{X}_{3}=\mathrm{Sex}$

$\mathrm{X}_{4}=$ Number of year of farming experience (NOPE)

$\mathrm{X}_{5}=$ Farm size $(\mathrm{FS})$

$\mathrm{X}_{6}=$ Do you have a regular source of income? (DHRSOI)

Logistic regression is commonly applied in the analysis of actions with binary outcomes. Chauke, Motlhatlhana et al., 2013; Isaga, 2018; and Silong and Gadanakis, 2019) applied it in identifying the determinants of access to credit. Equation 2 is the explicit model of logistic regression. Gerharda et al. (2018) worked on a similar subject but used what they called Finite mixture models by which they separated the observed data into two sub-components based on their presumption that members of the population belong to two unobserved sub-components. Differences in sociodemographic characteristics form the basis for separation with the implicit assumption that elements of the two subpopulations will respond differently to a set of psychological factors that are expected to affect saving behavior.

\section{RESULTS AND DISCUSSION}

\subsection{Socioeconomic characteristics of the respondents}

Table 1 shows the socioeconomic characteristics of respondents. Their ages ranged from 23 to 82 years with a mean of 47 years as against Nigeria's life expectancy of 54 years (Arikpo et al., 2019). Out of the 150 respondents, 38\% (57) were female and $62 \%$ (94) were male. Male, therefore, constitute the majority of the farming population (Anderson et al., 2017). This average age of farmers collaborates those of (Adepoju and Olapade, 2015; Ademola and Abang, 2015; and Adedejebi, 2019). The average age of 47 is delicately close to the life expectancy of Nigeria of 54 years and 13 years short of the official retirement age of 60 years, though it may not apply to farmers. But access to credit is negatively related to age (Aladejebi et al., 2018), thus there is a trade-off between age and access to bank credit, the need to balance whatever benefits that accompany age in farming with the credit access needs of farmers to financial institutions is indicated.

Furthermore, farm income-generating ability declines with age. Adepoju and Olapade (2015) observe that age and poverty have a negative correlation such that as the farmers get older farm income decreases and poverty increases. There is therefore a message for policymakers about farmers' age structure, the need to facilitate the entrant of youths into the farming business is signaled.

About $34 \%$ of respondents had no formal education. In other words, the majority $(66.2 \%)$ of the respondents had varying levels of formal education. A higher level of education makes for a higher likelihood of technology adoption (Ferrante and Sabatini, 2007) and financial literacy. Education opens up the mind, thus makes the farmer receptive to new and relevant technology and thereby constitutes a key driver of agricultural development (Anik et al., 2017). A positive correlation exists between education and farm output and productivity (Oduro et al., 2014); thus education is essential for the growth of the sector.

A relatively high proportion of the respondents $(52.00 \%)$ were either single $(44.67 \%)$ or single again $(7.33 \%)$, thus $48 \%$ were married. Marital status affects access to credit. Married farmers are viewed as more responsible and capable of loan repayment (Aladejebi et al., 2018) than the single, hence preferred in loan access. That less than 50\% are married may therefore not be a healthy 
development for loan access. Knowledge of this by the single farmers could discourage establishing a relationship with the banking system. Closely related to age is farming experience in terms of the number of years of involvement in farming activities. The mean number of years of experience which ranged from 1 to 36 years is 8.28 years. Experience is a component of human capital. However, it could also be a harbinger of resistant to change (Igwe et al., 2018) hence a balance needs to be struck between the aging farming population and new and young entrants if the sector is to be sustained both in terms of time and in terms of growth and development.

Household sizes ranged from 2 to 10 with a mean of 4 persons. Farm sizes were small ranging from 1 to 8 hectares with a mean of 2.9. This is higher than the national average of 1.9 hectares (Anderson et al., 2017), but maybe below economic size.

Table 1: Distribution of respondents on socio-economic characteristics

\begin{tabular}{|c|c|c|}
\hline Variable & Frequency & Percentage \\
\hline \multicolumn{3}{|l|}{ Age } \\
\hline $23-32$ & 37 & 24.67 \\
\hline $33-42$ & 30 & 20.00 \\
\hline $43-52$ & 26 & 17.33 \\
\hline $53-62$ & 17 & 11.33 \\
\hline $63-72$ & 17 & 11.33 \\
\hline $73-82$ & 23 & 15.34 \\
\hline Total & 150 & 100.0 \\
\hline \multicolumn{3}{|l|}{ Sex of Farmers } \\
\hline Female & 57 & 38.00 \\
\hline Male & 93 & 62.00 \\
\hline Total & 150 & 100.0 \\
\hline \multicolumn{3}{|l|}{ Education level } \\
\hline No formal education & 51 & 34.00 \\
\hline ND/NCE & 46 & 30.67 \\
\hline Bachelor/HND & 24 & 16.00 \\
\hline Postgraduate & 29 & 19.33 \\
\hline Total & 150 & 100.0 \\
\hline \multicolumn{3}{|l|}{ Marital status } \\
\hline Single & 67 & 44.67 \\
\hline Married & 72 & 48.00 \\
\hline Single Again & 11 & 7.33 \\
\hline Total & 150 & 100.0 \\
\hline \multicolumn{3}{|c|}{$\begin{array}{l}\text { Number of years of farming } \\
\text { experience }\end{array}$} \\
\hline $1-9$ & 25 & 16.67 \\
\hline $10-18$ & 28 & 18.67 \\
\hline $19-27$ & 47 & 31.33 \\
\hline $28-36$ & 50 & 33.33 \\
\hline Total & 150 & 100.0 \\
\hline
\end{tabular}

Source: Field survey, 2018

\subsection{Attitude towards Saving}

The issue sort to be determined here is the readiness and preparedness of farmers to save, that is, what they think about money, their perspective of money (Arifin, 2018). Hence the interest is on their financial knowledge. Farmers' scores in all 19 items of attitude towards saving are presented in Table 4.2. The scores were generally high for items that encourage saving and relatively low for items that discourage saving. This indicates that the respondents have high financial 
awareness/knowledge. For example, not one farmer disagreed with item (i) "It is important to save". This response indicates the desire to save. That they all agreed to this item could imply a readiness to save if their capacity to save and if the institutional conditions for saving are favourable. Farmers $(79.50 \%)$ do not like owing debt (item vii). This could be a reaction to the submission that traditional bank loans may not be supportive of small to medium enterprises (SMEs) at some stages of the firm's life cycle (OECD, 2015). They try to save as a matter of habit and saving is usually for precautionary reasons (94.70\%) (item v \& iii). Unfortunately, $91.40 \%$ of respondents are in search of alternative ways of saving (item iv) since they do not appear to be very comfortable with banking practices and maintaining bank account (items $\mathrm{x}$ and $\mathrm{xi}$ ). They desire to have a lot of money (items xii and xiv) thus they are frugal and prefer credit purchases to cash purchases (Items xii and xix, xvi and xviii). All these sum up to indicate the financial awareness of the respondents and their positive attitude to saving. Such conditions make for healthy financial practices (Arifin, 2018) and positively affect financial behaviour. Positive attitude towards saving engenders the desire to save and invest in the farm business. With expanded farm business and attendant higher volume of output and profit, financial planning will assume greater importance in the activities of these farmers (Arifin, 2018). The respondents are aware that savings come from income and the desire to have "a lot of money" (items xiii and xiv) which can only come from an expanded and profitable farm business.

\subsection{Test of Ho1: Farmer's attitude towards saving is not above average}

The mean scores of respondents on all attitudinal items were subjected to a one sample t-test using 2.50 as a test value for the hypothesis "Farmers' attitudes towards saving is not above average" The overall mean score was 2.59 with a standard deviation of 0.31 . The result $(\mathrm{t}=7.63$, $\mathrm{df}=150, \mathrm{P}=$ .04) was significant at $5 \%$ critical level. Hence the null hypothesis that farmers' attitudes towards saving are below average is rejected and the alternative accepted. In other words, farmers' attitude towards saving is positive, they have a mindset to save.

Table 2: Respondents attitude towards saving

\begin{tabular}{|c|c|c|c|c|c|c|}
\hline No. & Variables & SD & D & $\mathbf{A}$ & $\mathbf{S A}$ & $\begin{array}{c}\text { Mean Std. } \\
\text { Dev. }\end{array}$ \\
\hline i. & It is important to save & & & $22(14.6)$ & $129(85.4)$ & 3.85 \\
\hline ii & $\begin{array}{l}\text { You cannot get far without } \\
\text { saving }\end{array}$ & $7(4.6)$ & $9(6.0)$ & $58(38.4)$ & $77(51.0)$ & 3.36 \\
\hline iii & $\begin{array}{l}\text { I believe in putting some } \\
\text { money aside for a rainy day }\end{array}$ & $3(2.0)$ & $5(3.3)$ & $101(66.9)$ & $42(27.8)$ & 3.21 \\
\hline iv & $\begin{array}{l}\text { I am interested in looking at } \\
\text { different ways of saving } \\
\text { money }\end{array}$ & $3(2.0)$ & $10(6.6)$ & $105(69.5)$ & $33(21.9)$ & 3.11 \\
\hline $\mathrm{v}$ & I have always tried to save & & & & & 3.08 \\
\hline vi & $\begin{array}{l}\text { I believe in making my own } \\
\text { money }\end{array}$ & $3(2.0)$ & $22(14.6)$ & $95(62.9)$ & $31(20.5)$ & 3.02 \\
\hline vii. & I don't like being a debtor & 13(8.6) & 18(11.9) & 93(61.6) & 27(17.9) & 2.89 \\
\hline viii. & $\begin{array}{l}\text { I only save for something } \\
\text { special }\end{array}$ & $6(4.0)$ & $54(35.8)$ & $71(47.0)$ & $20(13.2)$ & 2.70 \\
\hline ix & $\begin{array}{l}\text { Never seem to have enough } \\
\text { money }\end{array}$ & $16(10.6)$ & $45(29.0)$ & $77(51.0)$ & $13(8.6)$ & 2.58 \\
\hline $\mathrm{x}$. & $\begin{array}{l}\text { Bank account is an everyday } \\
\text { necessity }\end{array}$ & $18(11.9)$ & $55(36.4)$ & $54(35.3)$ & $24(15.9)$ & 2.56 \\
\hline xi. & $\begin{array}{l}\text { Modern people use cheque } \\
\text { and card not cash }\end{array}$ & $17(11.3)$ & $70(46.4)$ & $45(29.8)$ & 19(12.6) & 2.44 \\
\hline xii & I love going for shopping & $26(17.2)$ & $75(49.7)$ & $28(18.5)$ & $22(14.6)$ & 2.30 \\
\hline xiii & $\begin{array}{l}\text { Having a lot of money has } \\
\text { never been my target in life }\end{array}$ & $37(24.5)$ & $74(49.0)$ & $26(17.2)$ & $14(9.3)$ & 2.11 \\
\hline
\end{tabular}




\begin{tabular}{|r|llllll}
\hline xiv & $\begin{array}{l}\text { I don't mind if I do not have } \\
\text { much money }\end{array}$ & $35(23.2)$ & $74(49.0)$ & $32(21.2)$ & $10(6.6)$ & 2.11 \\
\hline xv & $\begin{array}{l}\text { I never pay for something if I } \\
\text { can get credit }\end{array}$ & $16(10.6)$ & $92(60.9)$ & $29(19.2)$ & $14(9.3)$ & 2.27 \\
\hline xvi. & $\begin{array}{l}\text { I tend to spend money as soon } \\
\text { as I get it }\end{array}$ & $48(31.8)$ & $64(42.4)$ & $22(14.6)$ & $17(11.3)$ & 2.05 \\
\hline xvii & $\begin{array}{l}\text { I don't believe I will be ever } \\
\text { wealthy }\end{array}$ & $32(31.2)$ & $90(59.6)$ & $22(14.6)$ & $7(4.6)$ & 2.03 \\
\hline xviii. & $\begin{array}{l}\text { Money is for spending not for } \\
\text { holding onto }\end{array}$ & $86(57.0)$ & $19(12.6)$ & $3422.5)$ & $12(7.9)$ & 1.81 \\
\hline xix. & $\begin{array}{l}\text { Every once in a while like to } \\
\text { go on a big spending spree }\end{array}$ & $81(53.6)$ & $34(22.5)$ & $22(14.6)$ & $14(9.3)$ & 1.79 \\
\hline
\end{tabular}

Source: Field survey, 2018

Note: SD is strongly disagreed; D is disagreed; A is Agree, and SA strongly agrees. Figures in parentheses are percentages of total respondents

\subsection{Behaviour towards saving}

Ali et al. (2015) and Yonga et al. (2018) submitted that high financial knowledge positively influences saving and thus saving behaviour. The healthy saving attitude of the respondents has earlier been observed. Why they save and where they save are important in this section. Table 3 shows the items of farmers' behavior for saving. Most farmers (80\%) save. Anderson et al. (2017) have it that saving is common but not through formal methods. The major reasons for saving are spread across a wide spectrum. Only the primary reasons for saving are shown in Table 3 . The emergency (precautionary) reason is at the top (29.16\%) followed by children's education (25\%). Special purchases and "simply to have money put aside", both of which could be said to be speculative reasons, are next with $20 \%$ each way. These are the theoretical reasons for holding money taught in macroeconomic texts.

The "simply to have money put aside" motive could have an underlying influence of parental background. Salikin et al. (2012) submitted that education and level of household income have a negative correlation with the likelihood to save. In other words, the poorer the parents, the higher the likelihood of the offspring saving. Hence when there is no felt need to save, the inculcated practice of saving may underlie the saving behaviour of the individual farmer from low socioeconomic stratum.

As to what proportion of income respondents save, the answer varied widely. About $64.20 \%$ of farmers save $50 \%$ or more of their income. This is impressive. But where they save and what the denominator of this percentage is are equally important. The fact that credit still effectively constraints farming activities may indicate the paltry denominator of such saving/income percentage. The resulting measly amount saved may be consumed during the slack period when harvest is being awaited.

About $52.50 \%$ of farmers (Table 3) have no bank account. This finding is in agreement with the finding of Anderson et al. (2017) who submitted that notwithstanding the widespread saving practice among smallholder farmers, it is done outside the formal banking system. Hence a good proportion of $64.20 \%$ of farmers who save $50 \%$ or more of their income do so through informal methods. The absence of any formal relationship with the bank adversely affects loan access (Aladejebi et al., 2018). These savings may thus be handy and may not, therefore, fit into either the permanent income hypothesis or the Life Cycle hypothesis of consumption, saving, and income. However, every farm family to a large extent has a view of its expected expenditure over a farming cycle; hence the yearly income may be spread over the farming year thinly. For savings in kind like yam, those meant for consumption are separated from those meant for planting in the next season. Whereas the former is consumed over time until the next harvest, the latter is used in production in 
the next farming season; these are varieties of the traditional methods of saving and reasons holding cash. This pattern of saving/consumption may give credence to the relatively high proportion of farmers who do not operate a bank account, a behaviour which naturally eliminates them from accessing commercial bank loans (Aladejebi et al., 2018).

There is no compelling reason for these respondents to open a bank account. This is the most likely reason why $25.80 \%$ have simply not gone around getting one. Furthermore, they do not find them very helpful $(16.67 \%)$. The already unattractive situation is made worse by the long queues in banking halls due to slow service deliveries at the banks. These findings sum up to suggest that farmers have a desire to save but not in ways and manner currently offered by the commercial banks. Farmers like any other bank customer, require prompt services and, if any waiting periods, less stressful. These push factors from banking may, however, only represent hygiene factors which even if provided may not motivate farmers to have changed behaviour. Farmers already consider conditions for loan access very stringent and beyond their reach. Furthermore, their income situation has not been transformed. Necessary changes, therefore, need to be effected in these conditions to significantly touch farmers saving behaviour positively.

The fact of the existence of alternative sources of saving is noteworthy. The formation and membership of cooperative societies are on the increase so also are daily collectors who go to the farmer's doorstep to collect savings. About $46.67 \%$ of respondents either save with a cooperative society $(29.17 \%)$ or with daily collectors $(17.50 \%)$. Thus the formal banking sector may need to be more farmer oriented in their service delivery if they are to compete effectively in mobilizing rural farm income. Furthermore, since all the farmers who have bank account have visited the bank for reasons other than to make a deposit (Table 3), a possible implication is that ignorance and/or lack of awareness on the part of farmers regarding the traditional services of commercial banks may be on the decline but the environment of the banking system discourages general embraced by farmers.

\subsection{Determinants of saving}

Farming experience is a key determinant of saving. Table 4 which shows the farmers' perception of factors that affect saving indicates that about $95.33 \%$ of respondents were of this view. This finding suggests that competence/experience acquired over time has a penetrating effect on farming to saving behaviour, thus saving may have a positive relationship with good farming experience, all things being equal. On the other hand, low farm income, sex, age of respondent, and large household size tends to discourage saving (Table 4).

The logistic regression (Table 5) shows that educational level, farm size, and farming experience are the significant determinants of saving. The chances of saving increases with the level of education up to a point. This is evident in the exponents of the coefficients of the respective level of education. This finding implies increased training and education of farmers. Ali et al. (2015) recommended higher financial training such that it will have a positive influence on saving behaviour. Such an education level is ideal if saving from farm income is not to be diverted but harnessed for farm growth and development. Anang et al. (2015) did not find educational level significant but sex was at 5\%. Obalola et al. (2018) who used variables that have a little intersection with those of this study found age and farm income as significant determinants of saving. Farm income and farm size usually have a high correlation, hence there is a level of agreement between the two studies. 
Table 3: Distribution of respondents on behavior towards savings

\section{Variable}

Do you save?

No

Yes

Total

If yes, why do you save?

My friends do

For special purchases

Children's education

For emergencies

Simply to have money put aside

Total

If you save, what proportion of income do you save?

$25 \%$

$50 \%$

$75 \%$

Nearly all

Practically nothing

Total

I have a personal bank account?

(i) No

(ii) Yes

Total

If no, why not?

(i) I do not have enough saving

(ii) I simply have not gone around to get one

(iii) Banks are never open

(iv)I do not like standing in long queues waiting to be served

(v) I do not find them very helpful

Total

For which of the following reason have you visited your bank?

(i) To obtain advice about saving money

(ii) To get loan

(iii) To arrange an overdraft

(iv) The manager asked to see me

Total

How often do you save?

(i) Daily

(ii) Weekly

(iii) Monthly

Total

Where do you save money?

(i) Cash box at home

(ii) Daily saving collector

(iii) Bank

(iv) Cooperative society

Total
Frequency (\%)

$30(20.00)$

$120(80.00)$

$150(100.00)$

$15(12.50)$

$20(16.67)$

$30(25.00)$

35 (29.16)

$20(16.67)$

$120(100)$

$39(32.50)$

$45(37.50)$

$21(17.50)$

$11(9.17)$

$4(3.33)$

$120(100)$

$63(52.50)$

$57(47,50)$

$120(100)$

$8(6.67)$

$31(25.83)$

$24(20.00)$

$37(30.83$

$20(16.67)$

$120(100)$

$39(32.50)$

$56(47.00)$

$8(6.60)$

$17(13.90)$

$120(100)$

$26(21.90)$

37 (31.10)

$57(47.00)$

$120(100)$

$16(13.33)$

$21(17.50)$

$48(40.00)$

35 (29.17)

$120(100)$

Source: Field survey, 2018 
Obayelu (2012) identified farming experience as a significant determinant of saving in addition to age and diversification into non-farm activities. Farming experience is significantly negatively correlated in this study. The meaning of all these is that the factors that indeed determine savings may vary from place to place. This assertion requires a more comprehensive model in terms of variables for its validity.

Table 4: Farmers' perception of factors that affect saving

\begin{tabular}{lcc}
\hline Variable & Yes & No \\
\hline $\begin{array}{l}\text { Older farmers tend to save more } \\
\text { Male farmers are believed to save more than female }\end{array}$ & $51(34.00 \%)$ & $99(66 \%)$ \\
farmers & $32(21.33 \%)$ & $118(78.67 \%)$ \\
Farmers with good farming experience save more & $143(95.33 \%)$ & $7(4.67 \%)$ \\
$\begin{array}{l}\text { Farmers with large household tend to save less } \\
\text { Low income from rural enterprises leaves only a }\end{array}$ & $130(86.67 \%)$ & $20(13.33 \%)$ \\
little or nothing to savings & $141(94 \%)$ & $9(6 \%)$ \\
Farmers with self control towards spending save less & $30(20 \%)$ & $120(80 \%)$ \\
$\begin{array}{l}\text { Farmers that are not able to manage their resources } \\
\text { very well save more. }\end{array}$ & $16(10.67)$ & $134(89.33 \%)$ \\
\hline
\end{tabular}

Source: Field survey, 2018

Table 5: Logistic regression result of socio-economic factors as determinants of saving

\begin{tabular}{llcccccc}
\hline & B & S.E & Wald & df & Sig. & Exp(B) \\
\hline \multirow{6}{*}{ Age } & 0.007 & 0.012 & 0.325 & 1 & 0.569 & 1.007 \\
& Sex (1) & 0.355 & 0.489 & 0.525 & 1 & 0.469 & 1.426 \\
& Education & -2.052 & & 10.332 & 3 & $0.016^{*}$ & \\
& Education (1) & 1.003 & 0.819 & 6.276 & 1 & $0.012^{*}$ & 0.129 \\
Step1 $^{\text {a }}$ & Education (2) & -0.432 & 0.866 & 1.342 & 1 & 0.247 & 0.367 \\
& Education (3) & 0.161 & 0.964 & 0.201 & 1 & 0.654 & 0.649 \\
& Farm size & -0.048 & 0.061 & 6.991 & 1 & $0.008^{* *}$ & 1.175 \\
& Farming experience & 0.777 & 0.021 & 5.328 & 1 & $0.021^{*}$ & .953 \\
& Regular income source (1) & 0.648 & 0.594 & 1.712 & 1 & 0.191 & 2.176 \\
Constant & & 1.145 & 0.321 & 1 & .0571 & 1.913 \\
\hline
\end{tabular}

Source: Field survey, 2018

\subsection{Challenges to farmers saving}

Eight factors that could constitute challenges to farmers in their saving efforts were assessed by farmers. Table 6 shows their responses and the ranking of these factors. All the items scored highly above a mean of 2.50 usually applied to a four-point Likert type scale. At the top is inadequate income, followed by family responsibility and cost of inputs. Again, inadequate income and cost of inputs are two sides of the same coin. Demand tends to push up the cost of inputs at peak activity periods of farming. On the other hand, an uncontrolled supply of farm output to the market during harvest tends to drive down the price of outputs. This is the dilemma of farmers to whom value addition to produce is not common in an unorganized market. It is for this reason that we recommend that policies that boost farmers' income and would make for the development of an organized market should be pursued. Also, that the banking sector should be more customers oriented with particular attention to the needs of rural farmers. 
Table 6: Respondents' perception of challenges to saving

\begin{tabular}{|c|c|c|c|c|c|c|c|}
\hline No. & & SD \%) & $\mathrm{D}(\%)$ & A $(\%)$ & SA $(\%)$ & $\begin{array}{c}\text { Mean } \\
\text { (Std) }\end{array}$ & Rank \\
\hline i. & Inadequate income & $3(2.00)$ & $6(4)$ & $38(25.33)$ & $103(68.67)$ & $3.89(0.69)$ & $1^{\mathrm{st}}$ \\
\hline ii. & Family responsibility & & $8(6.33)$ & $45(30)$ & $97(64.67)$ & $3.58(0.61)$ & $2^{\text {nd }}$ \\
\hline iii. & Cost of inputs & & $14(9.33)$ & $61(40.67)$ & $75(50)$ & $3.40(0.66)$ & $3^{\text {rd }}$ \\
\hline iv. & $\begin{array}{l}\text { Lack of trust of security } \\
\text { of savings }\end{array}$ & $9(6.00)$ & $29(19.33)$ & $46(30.67)$ & $66(44)$ & $3.11(0.93)$ & $4^{\text {th }}$ \\
\hline v. & $\begin{array}{l}\text { Insincerity of group } \\
\text { members pose a problem } \\
\text { to farmers income }\end{array}$ & $7(4.67)$ & $15(10)$ & $85(56.67)$ & $43(28.67)$ & $3.10(0.76)$ & $5^{\text {th }}$ \\
\hline vi. & Theft of crops & $6(4.00)$ & $28(18.67)$ & $62(41.33)$ & $54(36)$ & $3.09(0.84)$ & $6^{\text {th }}$ \\
\hline vii. & $\begin{array}{l}\text { High bank charges, } \\
\text { delays, congestion at the } \\
\text { bank and remoteness of } \\
\text { the bank hinder farmers } \\
\text { saving }\end{array}$ & $10(6.67$ & $13(8.67)$ & $83(55.33)$ & $44(29.33)$ & $3.08(0.80)$ & 7 th \\
\hline viii. & Constant illness & $8(5.33)$ & $19(12.67)$ & $87(58)$ & $36(24)$ & $3.01(0.766)$ & $8^{\text {th }}$ \\
\hline
\end{tabular}

Source: Field survey, 2018

\section{CONCLUSION}

Farmers are knowledgeable on the need to saving and have a mindset to saving, but generally not in the formal banking system. Apart from inadequate income and family responsibilities which act against saving, they are ill provided for by demographic factors such as age, marital and educational status outside those required by the formal banking sector. The chances of saving of an educated farmer are higher than those for a farmer without formal education. These factors affect the attitudes farmers have towards formal financial institutions such as commercial banks but not towards saving. Thus they prefer alternative avenues for saving thus they are in search of alternative methods of saving.

\footnotetext{
Funding: This study did not receive any specific financial support.

Competing Interests: The authors declared that they have no conflict of interests.

Contributors/Acknowledgement: All authors participated equally in designing and estimation of current research.

Views and opinions expressed in this study are the views and opinions of the authors, Asian Journal of Agriculture and Rural Development shall not be responsible or answerable for any loss, damage or liability, etc. caused in relation to/arising out of the use of the content.
}

\section{References}

Adedejebi, O. (2019). Determinants of lending to small and medium enterprises by deposit banks in Nigeria. The International Journal of Business \& Management, 7(3), 121-131. doi.org/10.24940/theijbm/2019/v7/i3/bm1903-029.

Adepoju, A. A., \& Olapade, O. F. (2015). Effect of non-farm income on poverty status among rural farmers in southwest Nigeria. Journal of Hill Agriculture, 6(2), 197-201. doi.org/10.5958/2230-7338.2015.00043.9.

Ademola, A. A., \& Abang, S. O. (2015). Analysis of poverty status of rural farm families in Akwa Ibom State, Nigeria. Global Journal of Agricultural Sciences, 14, 45-50. doi.org/10.4314/gjass.v14i1.6.

Aladejebi, O. J., Omolehin, R. A., Ajiniran, M. E., \& Ajakpovi, A. P. (2018). Determinants of credit acquisition and utilization among Household farmers in the drive towards sustainable 
output in Ekiti State, Nigeria. OIDA International Journal of Sustainable Development, 11(9), 25-36.

Albu, M., \& Scott, A. (2001). Understanding livelihoods that inve micro-enterprise: markets, and technological capacities in the SL framework, Intermediate Technology Development ground war Wickshire. Intermediate Technology Development Group Practical Answers to Poverty. Retrieved from https://www.microfinancegateway.org.

Ali, A., Rahman, M. S., \& Bakar, A. (2015). Financial satisfaction and the influence of financial literacy in Malaysia. Social Indicator Research, 120(1), 137-156. Retrieved from https://link.springer.com/article/10.1007/s11205-014-0583-0.

Anang, B. T., Dawuda, I., \& Imoro, L. (2015). Determinants of savings habit among Clients Bonzali rural bank in the Tolon-Kumbungu district of Ghana. UDS International Journal of Development, 2(2), 88-97.

Anderson, A., Marita, C., Musiime, D., \& Thiam, M. (2017). National survey and segmentation of smallholder households in Nigeria: Understanding their demand for financial, agricultural, and digital solutions. CGAP Working Paper. Retrieved from https://www.cgap.org/sites/default/files/Working-Paper-Survey+Segmentation-ofSmallholders-Nigeria-Oct-2017.pdf

Anik, A. R., Rahman, S., \& Sarker, J. R. (2017). Agricultural productivity growth and the role of in South Asia (1980-2013). Sustainability, 9(3), 1-24. doi.org/10.3390/su9030470.

Arifin, A. Z. (2018). Influence factors toward financial satisfaction with financial behavior as intervening variable on Jakarta area workforce. European Research Journal, 21(1), 90-103. doi.org/10.35808/ersj/932.

Arikpo, D. I., Eke, F. A., \& Obafemi, F. N. (2019). Determinants of life expectancy in Nigeria: A macroeconomic analysis. International Journal of Social Science and Economic Research, 4(4), 2722-2749.

Chauke, P. K., Motlhatlhana, M. L., Pfumayaamba, T. K., \& Anim, F. D. K. (2013). Factors influencing access to credit: A case study of smallholder farmers in the Capricorn district of South Africa. African Journal of Agricultural Research, 8(7), 582-585

Fadeyi, O. A. (2018). Smallholder agricultural finance in Nigeria: The research gap. Journal of Development and Agricultural Economics, 10(11), 367-376.

Ferrante, F., \& Sabatini, F. (2007). Education, social capital and entrepreneurial selection in Italy. MPRA Paper No. 2451. Retrieved from http://mpra.ub.uni-muenchen.de/2451/MPRA.

Furnham, A. (1999). Spending and saving attitudes and behaviors questionnaire. Retrieved from https://is.cuni.cz/webapps/zzp/download/130141120.

Gerharda, P., Gladstonec, J. J., \& Hoffmann, A. O. (2018). Psychological characteristics and household savings behavior: The importance of accounting for latent heterogeneity. Journal of Economic Behaviour and Organization, 148, 66-82.

Ghafoor, A., Hussain, M., Naseer, H., Ishaque, M., \& Baloch, M. H. (2010). Factors affecting income and saving of small farming households in Sargodha district of the Punjab, Pakistan. Pakistan Journal of Agricultural Engineering \& Veterinary Science, 26(2), 27-35.

Hogg, M., \& Vaughan, G. (2005). Social psychology ( $8^{\text {th }}$ edition) London. Pearson Education Limited. Retrieved from https://www.nousharek.com.

Igwe, P. A., Amaugo, A. N., Ogundana, O. M., Odafe, M. E., \& Anigbo, J. A. (2018). Factors Affecting the Investment Climate, SMEs Productivity and Entrepreneurship in Nigeria. European Journal of Sustainable Development, 7(1), 2239-2259.

Isaga, N. (2018). Access to bank credit by smallholder farmers in Tanzania: a case study. Afrika Focus, 31(1), 241-256. doi.org/10.21825/af.v31i1.9048.

Obalola, T. O., Audu, R. O., \& Danilola, S. T. (2018). Determinants of Savings among Smallholder Farmers in Sokoto South Local Government Area, Sokoto State, Nigeria. Acta agriculturae Slovenica, 111(2), 341-347.

Obayelu, O. A. (2012). Saving behavior of rural households in Kwara State, Nigeria. African Journal of Basic \& Applied Sciences, 4(4), 115-123. 
Odoemenem, I. U., Ezihe, J. A. C., \& Akerele, S. O. (2013). Saving and investment pattern of small-scale farmers of Benue State, Nigeria. Global Journal of Human Social Science Sociology and Culture, 13(1), 7-12.

Oduro, O. E., Aboagye, A. P., \& Acquaye N. A. E. (2014). Effects of education on the agricultural productivity of farmers in the Offinso municipality. International Journal of Development Research, 4(9), 1951-1960.

OECD (2015). New approaches to SME and entrepreneurship financing: Broadening the range of instruments. Retrieved from https://www.oecd.org/cfe/smes/New-Approaches-SMEsynthesis.pdf.

Osondu, C. K., Obike, K. C., \& Ogbonna, S. I. (2015). Savings, income and investment patterns and its determinants among small holder arable crop farmers in Umuahia capital territory, Abia State, Nigeria. European Journal of Business and Innovation Research, 3(1), 51-70.

Oyelade, A., Ayeni, B. O., Ogundipe, M. O., Salusi, T. O., Tijani, O. D., \& Umah, I. E. (2019). Challenges and prospects of commercial bank loan extended to farmers in Lagelu local government of Oyo State, Nigeria. Asian Development Policy Review, 7(1), 31-42

Rahji, M. A. Y., \& Adeoti, A. I. (2010). Determinants of agricultural credit rationing by commercial banks in south-western Nigeria. International Journal of Finance and Economics, 37, 7-14.

Salikin, N., Wahab, N. A B., Zakaria, N., Masruki, R., \& Nordin, S. N. (2012). Students'saving attitude: does parents' background matter? International Journal of Trade, Economics and Finance, 3(6), 479-484.

Silong, A. K. F., \& Gadanakis, Y. (2019). Credit sources, access and factors influencing demand among rural livestock farmers in Nigeria. Journal of Agricultural Finance Review, 80(1) 68-90.

Sitharam, S., \& Hoque, M. (2016). Factors affecting the performance of small and medium enterprises in KwaZulu-Natal, South Africa. Problems and Perspectives in Management, 14(2-2), 277-288.

Waniak, M., H., Michalak, J., \& Gheribi, E. (2018). The sources of financing for SMEs in Poland. Management and Education, 14(1), 15-21.

Yonga, C., Yewb, S., \& Wee, C. (2018). Financial knowledge, attitude and behaviour of young working adults in Malaysia. Institutions and Economies, 10(4), 21-48.

Zeller, M., \& Sharma, M. (2000). Many borrow, more save and all insure: Implications for food and micro finance policy. Food Policy, 25, 143-167. doi.org/10.1016/s0306-9192(99)000652 . 